\title{
NOTES ON THE DISTRIBUTION OF BAILEY'S EASTERN WOODRAT (NEOTOMA FLORIDANA BAILEYI) IN NEBRASKA
}

\author{
Zebadiah R. Graham ${ }^{1}$, Keith Geluso ${ }^{1,3}$, and Russell A. Benedict ${ }^{2}$
}

\begin{abstract}
Aвstract.-The eastern woodrat (Neotoma floridana) occurs in eastern and central parts of the United States, with 3 subspecies inhabiting Nebraska. Herein, we report on distributional records of $N$. f. baileyi-an isolated, disjunct subspecies in north-central Nebraska. We searched for diagnostic sign of woodrats in 4 counties in Nebraska and 1 county in South Dakota. We obtained distributional records for $N$. f. baileyi east, west, and north of known distribution limits in Nebraska, but none in South Dakota. Most distributional records represent range extensions because of lack of prior mammalian surveys in those areas. Observations of woodrats in isolated, human-established woodlots surrounded by prairies represent range expansions because such habitats were not present in the past.
\end{abstract}

RESUMEN.-La rata cambalachera (Neotoma floridana) se encuentra en áreas orientales y centrales de los Estados Unidos; 3 de sus subespecies habitan en Nebraska. En el presente estudio, reportamos registros de distribución de $N$. $f$. baileyi-la cual es una subespecie aislada y separada que se encuentra en la parte norte-central de Nebraska. En 4 condados de Nebraska y en 1 de Dakota del Sur buscamos señales de la presencia de la rata cambalachera. Logramos obtener registros de distribución de $N$. f. baileyi al este, oeste y norte de los límites de distribución conocidos en Nebraska, pero no obtuvimos ninguno en Dakota del Sur. La mayoría de los registros de distribución representan extensiones del rango debido a la falta de exploraciones previas de mamíferos en esas áreas. Las observaciones de ratas cambalacheras en arboledas aisladas, establecidas por el ser humano y rodeadas por llanuras representan expansiones de su rango de distribución debido a que dichos hábitats no se encontraban en el pasado.

Three subspecies of the eastern woodrat (Neotoma floridana) occur in Nebraska. Neotoma floridana attwateri occurs in southeastern parts of the state (Fig. 1; Clausen 1998, Benedict et al. 2000), N.f. campestris occurs in south-central and southwestern Nebraska (Fig. 1; Kugler and Geluso 2009, Wills et al. 2011), and N.f. baileyi occurs in north-central Nebraska (Jones 1964, Birney 1973). The subspecies $N$. f. baileyi is an isolated, disjunct population that represents a glacial relict (Jones 1964). This population of eastern woodrats occurs only in cool canyons in the Niobrara River Valley and a few of its major tributaries in Cherry, Brown, Keya Paha, and Rock counties (Jones 1964, Birney 1973). In those counties woodrats inhabit houses constructed of sticks and other materials in rocky habitats along canyon walls, at bases of trees and logs in forested areas, and in abandoned buildings (Jones 1964, Birney 1973).

In recent decades, the distribution of eastern woodrats has expanded in southern Nebraska. Kugler and Geluso (2009) showed that N. $f$. campestris has expanded eastward along the
Republican River into Harlan and Webster counties since the 1960s, and Clausen (1998) reported a northward advancement of $N . f$. attwateri into southeastern Nebraska from Kansas along the Big Blue River drainage. With recent advancements of those subspecies in the state, we examined whether the other subspecies, $N$. f. baileyi, also had expanded its range in north-central Nebraska and possibly into South Dakota. Previously, a single eastern woodrat was reported from South Dakota (Spring Creek, 18 mi. SE Rapid City; Goldman 1910), but Jones (1964) determined that this individual represented a bushy-tailed woodrat (Neotoma cinerea). Distributional limits for N.f. baileyi were last updated by Birney (1973).

In 2004, 2009, 2010, and 2011, we searched for diagnostic signs of woodrats (i.e., their houses constructed from sticks and other materials) in 4 counties in Nebraska (Boyd, Cherry, Keya Paha, and Rock cos.) and 1 county in South Dakota (Todd Co.). Most sites represented areas outside distributional boundaries reported by Birney (1973) and Jones (1964; Fig. 1). Prior to surveys, we contacted

${ }^{1}$ Department of Biology, University of Nebraska at Kearney, Kearney, NE 68849

${ }^{2}$ Department of Biology, Central College, Pella, IA 50219

${ }^{3}$ Corresponding author. E-mail: gelusok1@unk.edu 


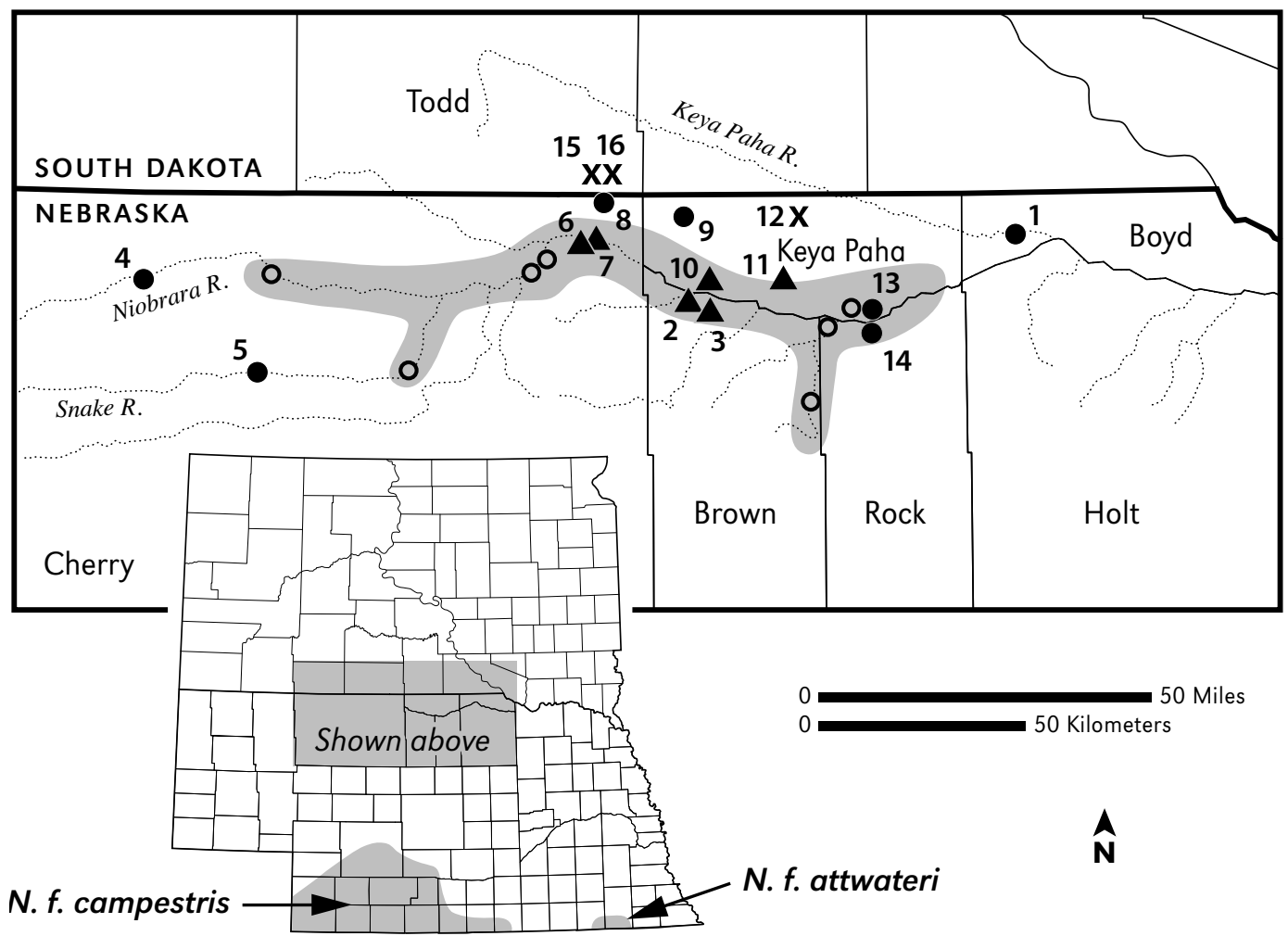

Fig. 1. Distribution of Bailey's eastern woodrat (Neotoma floridana baileyi) in north-central Nebraska. Open circles represent localities where woodrats were reported by Jones (1964) and Birney (1973). Closed circles represent localities where we observed woodrats, and closed triangles represent previously unpublished records of vouchers housed in museums (Appendix). X's represent localities where we did not observe evidence of woodrats. The shaded area represents the former distribution of $N$. f. baileyi in Nebraska (Birney 1973). Numbers associated with symbols refer to locality descriptions in the Appendix. Current distributions of N. f. campestris (Kugler and Geluso 2009) and N. f. attwateri (Benedict et al. 2000) are shown on the smaller inset map of Nebraska.

private landowners who owned wooded areas within and beyond the Niobrara River Valley. We searched for woodrat houses in dense trees and areas with shrubs, around abandoned buildings, and inside abandoned cars.

At most new sites with evidence of woodrats, we set traps to capture individuals to prepare as voucher specimens; vouchers were deposited in the collection at the University of Nebraska State Museum, University of Nebraska, Lincoln (see Appendix). We also queried museums and databases (see Appendix) for unpublished voucher specimens of $N . f$. baileyi (Mammal Networked Information System last queried on 26 January 2012). Prior to trapping, we obtained approval for research from the Institutional Animal Care and Use Committee at the University of Nebraska at Kearney as well as scientific collecting permits from the states of
Nebraska and South Dakota. Common and scientific names of plants used herein are based on Kaul et al. (2006).

\section{Distribution}

We searched for N.f. baileyi at 8 locations in Nebraska and 2 in South Dakota (Fig. 1, Appendix), documented woodrats at 7 localities in Nebraska (localities 1, 4, 5, 8, 9, 13, and 14), and observed no evidence of them in South Dakota. Six other localities for $N$. f. baileyi (localities 2, 3, 6, 7, 10, and 11) were obtained from unpublished specimens housed in museums (Fig. 1, Appendix). We obtained distributional records for $N . f$. baileyi east, west, and north of known distribution limits in northcentral Nebraska (Fig. 1).

To the east, we captured woodrats along the Keya Paha River in Boyd County (locality 1, 
Fig. 1). This represents a $45-\mathrm{km}$ range extension eastward, as well as a previously undocumented river drainage for the subspecies. Woodrats and their houses were observed in dense forests in the floodplain and on forested slopes leading down to the river. In the flood plain, eastern red-cedars (Juniperus virginiana) and plains cottonwoods (Populus deltoides) were the dominant tree species. Green ash (Fraxinus pennsylvanica), elm (Ulmus spp.), dogwood (Cornus spp.), hackberry (Celtis occidentalis), western snowberry (Symphoricarpos occidentalis), and Russian-olive (Elaeagnus angustifolia) also were observed in limited numbers. Wooded slopes mainly contained bur oak (Quercus macrocarpa) with some eastern red-cedars and a few plains cottonwoods. Additional surveys are needed to determine distributional limits of $N$. $f$. baileyi in the area. It is unclear how woodrats reached the Keya Paha River, but we present the following plausible explanations: (1) woodrats dispersed eastward along the Niobrara River to the confluence with the Keya Paha River and then traveled back westward along the river, (2) woodrats traversed open areas between the 2 river drainages in eastern Keya Paha County or western Boyd County, and/or (3) woodrats were inadvertently transported by humans to the area during movement of hay stacks, old vehicles, or other items. In western Nebraska, for example, Benedict et al. (2000) reported a record of $N$. cinerea from Crescent Lake National Wildlife Refuge. That individual likely reached the refuge via transportation of furniture.

To the west, we documented woodrats along the Niobrara and Snake rivers in reaches of the rivers without former records of occurrence (localities 4 and 5, Fig. 1). Along the Niobrara River, we captured individuals at the base of bluffs along the river south of Merriman, Cherry County (locality 4, Fig. 1). Woodrats were captured in brushy forests consisting of green ash, eastern red-cedar, box-elder (Acer negundo), and plains cottonwood. Those individuals represent a $37-\mathrm{km}$ range extension to the west of the previously closest record south of Cody (Jones 1964). It is unclear whether this locality represents the westernmost site for this subspecies or whether the westernmost site occurs farther westward along the Niobrara River. Additional habitat appears to exist farther to the west of our new locality of occurrence. In Cherry County along the Snake River (locality 5, Fig. 1), we captured an individual in a large American plum (Prunus americana) thicket on the lower slope of an upland mixedgrass prairie adjacent to a marsh. On the north side of the river, woodrat houses were constructed mainly from cuttings of American plums. Other houses were observed on the south side of the river in relatively flat areas with trees consisting of green ash, hackberry, and eastern red-cedar. The houses on the south side were composed of various materials depending on proximity to various trees and shrubs. These records represent a $34-\mathrm{km}$ range extension to the west of other records of occurrence along the Snake River (22 mi. SW Valentine; Birney 1973). It is unknown how long woodrats have inhabited the area and how far the species occurs to the west along the Snake River.

To the north, we documented woodrats in 2 isolated woodlots with abandoned homesteads away from the Niobrara River Valley in Cherry and Keya Paha counties (localities 8 and 9, Fig. 1). Sites were $7.7 \mathrm{~km}$ and $7.1 \mathrm{~km}$ north of the nearest forested canyons of the Niobrara River Valley. Both woodlots were situated in upland habitats surrounded by short-grass prairies lacking rock outcrops, which represents a new habitat for this subspecies. Abandoned homesteads were $6.1 \mathrm{~km}$ apart. Each woodlot consisted of a mixture of deciduous (P. deltoides and Ulmus spp.) and coniferous trees (J. virginiana). Woodrat houses were observed in old abandoned buildings, old cars, and wooded areas. How woodrats originally reached those sites is unknown, but individuals might have dispersed across grasslands or might have been inadvertently transported to sites by humans. The woodlot in northern Cherry County is only $1.6 \mathrm{~km}$ south of the South Dakota state line. We searched for woodrats in 2 nearby woodlots in Todd County, South Dakota, without success (Appendix). One site was an occupied homestead with domestic dogs and cats, and the other was a woodlot dominated by J. virginiana with a few elms (Ulmus spp.).

\section{Range Expansion Versus Range Extension}

According to Frey (2009), the best method to conclude that extralimital records represent a range expansion is to demonstrate that the species was not present in the past, based on prior surveys. If historical sampling was inadequate, 
then extralimital records are best considered range extensions (Frey 2009). We propose that another way to conclude that a record is a range expansion is to show that a species now occurs in habitats not present in the past. Based on those definitions and lack of past surveys in areas where woodrats occur today (see Birney 1973, Jones 1964), our eastern (Boyd County) and western (Cherry County) distributional records represent range extensions. Birney (1973) searched for woodrats as far east as eastern Boyd and Holt counties but did not present specific localities. Birney (1973) also searched for woodrats along the Keya Paha River in South Dakota but not specifically along the river in Nebraska. In Cherry County, Birney (1973) stated he did not search west of the record south of Cody on the Niobrara River and does not mention any surveys on the Snake River. It is possible, however, that our records represent expansions, but without knowledge of past surveys, we cannot justify that conclusion (Frey 2009). Distributional records of woodrats in wooded, isolated homesteads in prairies away from river valleys in north-central Nebraska, however, represent an expansion in distribution because such woodlots were not present prior to human settlement, regardless of the lack of prior surveys at these homesteads.

In conclusion, $N$. $f$. baileyi is the only endemic mammal in Nebraska, yet to date, relatively little information has been published on this taxon. Although the subspecies occurs in a limited area in the north-central part of the state, the population appears stable and possibly increasing with increasing wooded habitats reported in grasslands throughout the Great Plains (e.g., Briggs et al. 2002). Observations that woodrats construct houses in plum thickets and in isolated woodlots in the region demonstrate that the subspecies might occur in other treeless or isolated wooded habitats in north-central Nebraska. Additional research is warranted to document its current distribution, which might further elucidate mechanisms of dispersal, and determine whether the species has recently expanded in the Niobrara River Valley and surrounding areas.
We thank Darren, Connie, Gina, and Sam McCarthy; Carl Frauen; Roy Breuklander; Steve Breuklander; Wade Andrews; and Casey Foster for access to their land. We also thank Lanell Graham for assistance with trapping, Angie Fox (University of Nebraska State Museum) for preparing the figure, and Kenneth Geluso (University of Nebraska at Omaha) and 3 anonymous reviewers for comments on earlier versions of this manuscript. Mammalian surveys in 2004 were funded by a grant awarded to Hugh H. Genoways from the Nebraska Game and Parks Commission.

\section{Literature Cited}

Benedict, R.A., H.H. Genoways, and P.W. Freeman. 2000. Shifting distributional patterns of mammals in Nebraska. Transactions of the Nebraska Academy of Sciences 26:55-84.

Birney, E.C. 1973. Systematics of three species of woodrats (Genus Neotoma) in central North America. Miscellaneous Publications, University of Kansas, Museum of Natural History 58:1-173.

Briggs, J.M., G.A. Hoch, And L.C. Johnson. 2002. Assessing the rate, mechanisms, and consequences of the conversion of tallgrass prairie to Juniperus virginiana forest. Ecosystems 5:578-586.

Clausen, M.K. 1998. New record of the eastern woodrat from southeastern Nebraska. Prairie Naturalist 30: 187-188.

FreY, J.K. 2009. Distinguishing range expansions from previously undocumented populations using background data from museum records. Diversity and Distributions 15:183-186.

Goldman, E.A. 1910. Revision of the wood rats of the genus Neotoma. North American Fauna 31:1-124.

Jones, J.K., JR. 1964. Distribution and taxonomy of mammals of Nebraska. University of Kansas Publications, Museum of Natural History 16:1-356.

Kaul, R.B., D. Sutherland, and S. Rolfsmeier. 2006. The flora of Nebraska. Institute of Agriculture and Natural Resources, University of Nebraska-Lincoln, Lincoln, NE.

Kugler, K.A., And K. Geluso. 2009. Distribution of the eastern woodrat (Neotoma floridana campestris) in southern Nebraska. Western North American Naturalist 69:175-179.

Wills, H.D., K. Geluso, E.J. Smits, J.T. SPRInGER, AND W.E. NEWTON. 2011. Notes on the distribution of eastern woodrats and hispid cotton rats in south-central Nebraska. Prairie Naturalist 43:127-129.

Received 7 November 2011 Accepted 13 February 2012 
APPENDIX. Localities examined for Bailey's eastern woodrats (Neotoma floridana baileyi) in Nebraska and South Dakota, and localities of previously unpublished voucher specimens from other researchers. Numbers preceding localities correspond to those locations in Fig. 1. Parentheses that follow localities include presence or absence of woodrats and museum numbers of our vouchers housed at the University of Nebraska State Museum, Lincoln (UNSM), as well as unpublished vouchers from other researchers housed at the University of Nebraska at Kearney (UNK); the Museum of Southwestern Biology, Albuquerque, New Mexico (MSB); Michigan State University Museum, East Lansing (MSU); and the Museum of Vertebrate Zoology, University of California, Berkeley (MVZ).

NEBRASKA: Boyd County: (1) $6.1 \mathrm{~km} \mathrm{~S}, 2.3 \mathrm{~km} \mathrm{~W}$ Naper, $42^{\circ} 54.525^{\prime} \mathrm{N}, 99^{\circ} 07.442^{\prime} \mathrm{W}$ (woodrats present; UNSM 30100). Brown County: (2) 4.75 mi S of Norden (MSU 17218) and (3) $16 \mathrm{mi}$. N, $10 \mathrm{mi} \mathrm{W}$ Ainsworth, Niobrara Valley Preserve (UNK 3961 and 3978). Cherry County: (4) $7.8 \mathrm{mi}$. S, $0.5 \mathrm{mi}$. E Merriman, T33N, R37W, Sec. 28, NW1/4, SW1/4 (woodrats present; UNSM 29012); (5) $35.5 \mathrm{~km} \mathrm{S,} 3.2 \mathrm{~km}$ W Cody, Snake River, $42^{\circ} 36.972^{\prime} \mathrm{N}, 101^{\circ} 16.915^{\prime} \mathrm{W}$ (woodrats present; UNSM 30101); (6) $1.1 \mathrm{mi}$. N, $0.1 \mathrm{mi}$. W Headquarters, Fort Niobrara National Wildlife Refuge (MSB 119407); (7) $2.6 \mathrm{mi} . \mathrm{N}, 1.3 \mathrm{mi}$. E Headquarters, Fort Niobrara National Wildlife Refuge (MSB 119413); and (8) $4.8 \mathrm{~km} \mathrm{~N}$, $1.5 \mathrm{~km}$ E Sparks, $42^{\circ} 59.072^{\prime} \mathrm{N}, 100^{\circ} 14.085^{\prime} \mathrm{W}$ (woodrats present, UNSM 30098 and 30099). Keya Paha County: (9) $1.1 \mathrm{~km}$ N, $6.4 \mathrm{~km}$ E Sparks, $42^{\circ} 57.016^{\prime} \mathrm{N}, 100^{\circ} 10.592^{\prime} \mathrm{W}$ (woodrats present); (10) $2.5 \mathrm{mi} . \mathrm{S}, 13 \mathrm{mi}$. W Springview (UNK 3652 ); (11) $3 \mathrm{~km} \mathrm{S,} 2 \mathrm{~km} \mathrm{~W}$ Springview (MVZ 181284); (12) Holt Creek Wildlife Management Area, $16.5 \mathrm{~km} \mathrm{~N}, 2.9 \mathrm{~km} \mathrm{E}$ Springview, $42^{\circ} 57.818^{\prime} \mathrm{N}, 99^{\circ} 42.490^{\prime} \mathrm{W}$ (woodrats not present); and (13) $10.9 \mathrm{~km} \mathrm{~S}, 15.0 \mathrm{~km} \mathrm{E}$ Springview, $42^{\circ} 43.595^{\prime} \mathrm{N}$, $99^{\circ} 33.869^{\prime} \mathrm{W}$ (woodrats present). Rock County: (14) Fred Thomas State Wildlife Management Area, $15.7 \mathrm{~km} \mathrm{~N}, 4.3 \mathrm{~km} \mathrm{~W}$ Bassett, $42^{\circ} 43.261^{\prime} \mathrm{N}, 99^{\circ} 35.326^{\prime} \mathrm{W}$ (woodrats present).

SOUTH DAKOTA: Todd County: (15) $6.5 \mathrm{~km} \mathrm{~N}, 1.4 \mathrm{~km}$ E Sparks [Nebraska], $42^{\circ} 59.947^{\prime} \mathrm{N}, 100^{\circ} 14.366^{\prime} \mathrm{W}$ (woodrats not present) and (16) $6.5 \mathrm{~km} \mathrm{~N}, 2.3 \mathrm{~km}$ E Sparks [Nebraska], 42 $59.981^{\prime} \mathrm{N}, 100^{\circ} 13.720^{\prime} \mathrm{W}$ (woodrats not present). 